\title{
Resistance of oat cultivars to reduction in fungicide use and a longer interval from application to harvest to promote food security
}

\author{
E.F. Dornelles ${ }^{1}$, J.A.G. da Silva ${ }^{1}$, I.R. Carvalho ${ }^{1}$, O. Alessi ${ }^{1}$, V. Pansera ${ }^{1}$, \\ F. Lautenchleger ${ }^{2}$, E.M.F. Stumm ${ }^{1}$, R. Carbonera ${ }^{1}$, R.L. Bárta ${ }^{1}$ and \\ J.V. Tisott ${ }^{1}$ \\ ${ }^{1}$ Universidade Regional do Centroeste do Estado do Rio Grande do Sul, Ijuí, \\ RS, Brasil \\ ${ }^{2}$ Universidade Estadual do Oeste do Paraná, Guarapuava, PR, Brasil \\ Corresponding author: I.R. Carvalho \\ E-mail: carvalho.irc@gmail.com \\ Genet. Mol. Res. 19 (2): gmr18542 \\ Received December 16, 2019 \\ Accepted May 28, 2020 \\ Published June 30, 2020 \\ DOI http://dx.doi.org/10.4238/gmr18542
}

\begin{abstract}
The resistance of oat cultivars to fungicide use reduction and supporting longer harvest application interval can reduce or avoid the risk of food contamination and environmental pollution. We compared oat cultivars for resistance to reduction in the number of fungicide applications and with longer intervals from application to harvest, considering favorable and unfavorable crop year conditions and how they affect yield and progress of major leaf diseases. The study was conducted in 2015, 2016 and 2017, in Augusto Pestana, RS, Brazil. The experimental design was a complete randomized block with three replications in a $22 \times 4$ factorial scheme for 22 oat cultivars recommended for cultivation in Brazil and four conditions of fungicide use: no application; one application 60 days after emergence; two applications at 60 and 75 days after emergence and; three applications at 60,75 and 90 days after emergence. In the control of leaf diseases, the fungicide FOLICUR ${ }^{\circledR}$ CE was used in 2015 and 2016 and the fungicide PRIMO ${ }^{\circledR}$ in 2017 at dosages of 0.75 and 0.3 liters ha $^{-1}$, respectively. Most of the oat cultivars had little addtional production with the third application of fungicide at 90 days after emergence. Therefore, we coulold increase the interval between application and harvest with
\end{abstract}


just two applications, at 60 and 75 days after and emergence. FAEM 4 Carlasul, URS Altiva and URS Guria cultivars gave high yields under most fungicide use conditions, allowing a long interval between the last application and grain harvest.

Key words: Avena sativa; Pesticide; Human food; Environmental quality

\section{INTRODUCTION}

White oats are an important alternative for diversification and economic contribution to agroculture in Brazil. Considered an extremely healthy foodstuff, it has been in high demand by the food industry due to its excellent nutritional value (Mantai et al., 2020; Silva et al., 2020). Grain yield is particularly of interest to farmers, and industrial productivity is desired for processing, as it requires well-formed grains with dimension greater than $2 \mathrm{~mm}$ and a greater percentage of caryopsis in relation to husks (Alves \& Kist, 2010; Hawerroth et al., 2015).

The quality of oat grains coupled with a more demanding population for nutritious and healthy foods has contributed to increasing acreage dedicated to this crop (Silva et al., 2015; Romitti et al., 2017). However, the reduced genetic resistance of cultivars to leaf diseases has been making it difficult to control them, causing irreversible damage to production (Tormen et al., 2013; Souza et al., 2015).

Among leaf diseases by fungi, leaf rust (Puccinia coronata Cda.f.sp. avenae) and helminthsporiosis [Drechslera avenae (Eidam) El Sharif] have been receiving the most attention (Martinelli et al., 2009; Dietz, Schierenbeck, Simón, 2019). These diseases are not satisfactorily controlled by genetic resistance (Kuhnem et al., 2009; Montilla-Bascón et al., 2015). The use of fungicides is the most efficient way to promote grain yield and quality (Oliveira et al., 2007; Tormen et al., 2013; Silva et al., 2015). Most oat grains are used in the preparation of fresh foods, so the most efficient and sustainable management of the fungicide is decisive in preventing or decreasing contamination of food and the environment (Tormen et al., 2013; Oliveira et al. al., 2015).

The identification of oat cultivars with greater resistance to reducing fungicide use and supporting longer application intervals to harvest can reduce or avoid the risk of food contamination and environmental pollution, promoting greater cultivation sustainability. Thus, our objective was to identify oat cultivars more resistant to reduction in the number of fungicide applications with greater interval from application to harvest, considering favorable and unfavorable crop year conditions to yield and progress of major leaf diseases.

\section{MATERIAL AND METHODS}

The work was developed in 2015, 2016 and 2017, in Augusto Pestana, RS, Brazil (28 $26^{\prime} 30^{\prime} \mathrm{S}$ latitude and $54^{\circ} 00^{\prime} 58^{\prime} \mathrm{W}$ longitude). The soil of the experimental area is classified as typical dystroferric red latosol (Oxisol). The climate of the region, according to Köppen classification, is of humid subtropical type. Before sowing, soil analysis was performed and the following chemical characteristics were identified: $\mathrm{pH}=6.3 ; \mathrm{P}=34.1$ mg. $\mathrm{dm}^{-3} ; \mathrm{K}=198 \mathrm{mg} . \mathrm{dm}^{-3} ; \mathrm{OM}=3.2 \% ; \mathrm{Al}=0 \mathrm{cmol}_{\mathrm{c}} \cdot \mathrm{dm}^{-3} ; \mathrm{Ca}=6.5 \mathrm{cmol}_{\mathrm{c}} \cdot \mathrm{dm}^{-3}$ and $\mathrm{Mg}=$ $2.5 \mathrm{cmol}_{\mathrm{c} .} \mathrm{dm}^{-3}$. The experimental plot consisted of 5 lines of $5 \mathrm{~m}$ in length and line spacing 
of $0.2 \mathrm{~m}$ to compose the experimental unit of $5 \mathrm{~m}^{2}$. The population density used was 400 viable seeds $\mathrm{m}^{-2}$, according to the technical recommendation. To meet the expected grain yield of 4 t.ha ${ }^{-1}, 10 \mathrm{~kg} \cdot \mathrm{ha}^{-1}$ of nitrogen was applied to the base, and the remaining for topdressing at the fourth expanded leaf stage. In addition, based on soil $\mathrm{P}$ and $\mathrm{K}$ contents, 45 and $30 \mathrm{~kg} \cdot \mathrm{ha}^{-1}$ of $\mathrm{P}_{2} \mathrm{O}_{5}$ and $\mathrm{K}_{2} \mathrm{O}$ were applied at sowing, respectively.

The experimental design was a randomized complete block with three replications in a $22 \times 4$ factorial scheme for 22 oat cultivars and four conditions of fungicide use. The oat cultivars analyzed represent those recommended for cultivation in Brazil, as follows: URS Altiva, URS Brava, URS Guará, URS Estampa, URS Corona, URS Torena, URS Charrua, URS Guria, URS Tarimba, URS Taura, URS 21, URS Fapa Slava, FAEM 007, FAEM 006, FAEM 5 Chiarasul, FAEM 4 Carlasul, Brisasul, Barbarasul, IPR Afrodite, UPFPS Farroupilha, UPFA Ouro and UPFA Gaudéria. The conditions of fungicide use were: [control (without application); an application 60 Days After Emergency (DAE); two applications at 60 and $75 \mathrm{DAE}$; and three applications at 60, 75 and 90 DAE]. The conditions of fungicide use were proposed based on the possibility of altering the intervals between harvest and last application of the pesticide (fungicide), considering the protection period of 15 to 20 days after its application, as indicated by the product. The application at 90 DAE was defined to ensure a considerable interval between last fungicide application and grain maturity (around 30 days), ensuring no application at full grain filling (Table 2, 3, 4).

For the control of leaf diseases, the fungicide FOLICUR ${ }^{\circledR}$ CE was used in 2015 and 2016 and the fungicide PRIMO® in 2017 at the dosages of 0.75 and 0.3 liters ha ${ }^{-1}$, respectively. The variables analyzed were necrotic leaf area (NLA, \%) and grain yield (GY, $\left.\mathrm{kg} \mathrm{ha}^{-1}\right)$. In determining the necrotic leaf area, three plants were randomly collected from each plot. The plants were collected at 60, 75, 90 and 105 days after emergence for all cultivars and fungicide use conditions. From each plant, the three upper leaves were removed to evaluate the leaf area. The leaves were scanned using a leaf area reader and WinDIAS software (Copyright 2012, Delta-T Devices Limited) to determine the disease necrosis area over the total leaf area. In the grain yield estimation, we considered the three central lines of each plot, harvested manually when the grains had moisture of about $15 \%$. The plants were processed with a stationary harvester and directed to the laboratory to correct grain moisture to $13 \%$ and determine the yield converted to kg.ha ${ }^{-1}$.

Data were subjected to analysis of variance to detect the main effects and interactions of "cultivars" and "condition of fungicide use". For each fungicide condition, the cultivars were classified as superior (S) or inferior (I), considering the mean plus or minus one standard deviation. Scott \& Knott's averaging test was performed to test the performance of each cultivar based on the number / moment of pesticide use, analyzing the interval between harvest and last application of the fungicide. The analyses were performed with the aid of GENES software (Quantitative Genetics and Experimental Statistics, version 2015.5.0).

\section{RESULTS AND DISCUSSION}

In 2017 (Table 1), air temperature values were higher compared to 2015 and 2016 and with considerable instability in the vegetative phase. The greatest precipitation occurred in the grain filling phase. The reduced soil moisture at the moment of nitrogen application 
and the high temperature during the cycle (Figure 1A) were decisive for the lower nutrient absorption efficiency, compromising the expected yield of $4000 \mathrm{~kg} \cdot \mathrm{ha}^{-1}$ and a more directly linked analysis to the effects of the disease. Under these conditions the overall average grain yield, regardless of the fungicide application condition was $1861 \mathrm{~kg} \cdot \mathrm{ha}^{-1}$ (Table 1). Average yields compared to the expected confirm an unfavorable agricultural year (UY) for oat cultivation and the progress of leaf diseases.

Table 1. Temperature and rainfall in the oat crop cycle and grain yield under various fungicide use conditions.

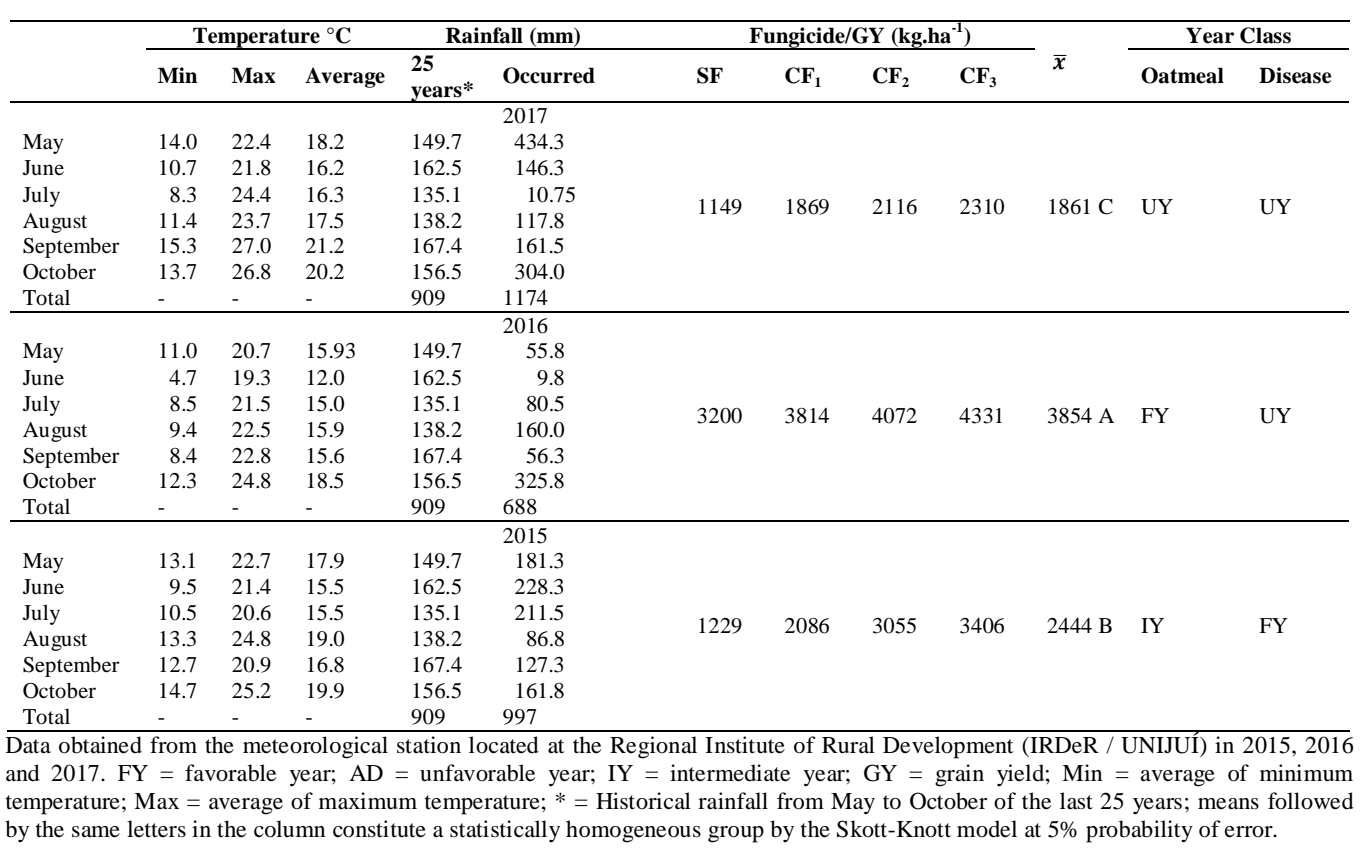

In 2016 (Table 1), the lowest values of air temperature and stability throughout the cycle were observed. Rainfall, although lower than the historical average, showed adequate distribution (Figure 1B).

Although during grain filling there was considerable rain, temperatures were mild, a condition that hindered the development of leaf diseases. Nitrogen was applied under adequate soil moisture conditions due to rainfall in previous days. According to Table 1, the average yield was close to the expectation $\left(4000 \mathrm{k}\right.$ ha $\left.{ }^{-1}\right)$, a condition that ranks 2016 as a favorable year (FY) for oat cultivation and unfavorable (UY) to leaf diseases.

In 2015, temperatures had medium to high values and with greater stability compared to 2017. Rainfall was similar to the historical average of the last 25 years, but with high rainfall during the development cycle. Soil moisture condition was observed in the nitrogen application due to rainfall before the nutrient application. The conditions of medium to high air temperature and rainfall during the cycle in 2015 indicated a favorable environment for the development of leaf diseases. The yield obtained was below the 
expectation, although the nitrogen application conditions were favorable (Figure 1C). The yield values obtained support the classification of the year 2015 as intermediate (IY) for oat cultivation and favorable (FY) for leaf diseases. This was an advantageous condition for analysis of disease effect and characterization of cultivars more resistant to fungicide reduction.

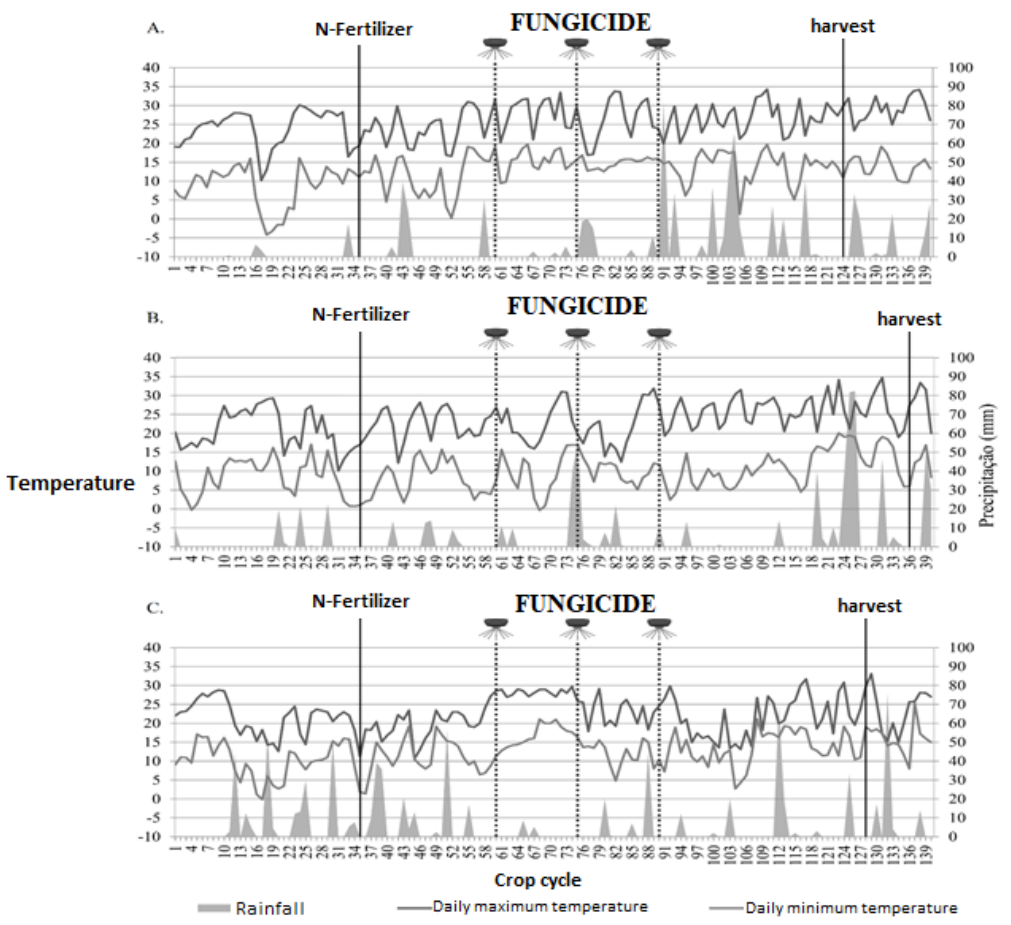

Figure 1. Data of rainfall and daily minimum and maximum temperature during oat cultivation cycle: (A) agricultural year 2017, (B) agricultural year 2016 and (C) agricultural year 2015.

Cordeiro et al. (2015) highlight the strong influence of meteorological elements on the productivity of winter species, requiring lower temperatures and adequate rainfall distribution. In oats, milder temperatures with sunlight and rainfall that maintain acceptable soil moisture characterize an environment conducive to increased grain yields (Souza et al., 2013). Large volumes and/or intensity of rainfall after nitrogen applications reduce the efficiency of plant utilization due to lack of oxygenation and nutrient losses by leaching. Elevated temperatures also reduce the efficiency of nutrient use because of volatilization (Scremin et al., 2017). The severity of leaf diseases in winter crops is directly related to weather conditions during the growing season, especially rainfall and air temperature (Castro et. al., 2012). Average temperatures above $20^{\circ} \mathrm{C}$, coupled with high humidity levels, characterize a favorable environment for the development of fungi that cause leaf diseases (Karise et al., 2016). In oats, the most prevalent and aggressive fungi under the reported environmental conditions are leaf rust (Puccinia coronata Cda. F.sp. avenae) and helminthsporiosis [Drechslera avenae (Eidam) El Sharif], causing major damage to the area and consequently to grain yield (Dietz Simón, 2019). 
In Table 2, in the unfavorable year (UY) for oat cultivation and disease progression (UY) (2017), significant values of necrotic leaf area were observed, both due to the disease and the effect of water restriction and high temperatures. The weather conditions were decisive to reduce productivity and promote leaf necrosis, drastically reducing the desired productivity expectation.

In general, most cultivars presented higher yields with only two fungicide applications. It is noteworthy that even with the fungicide in the third application at 90 days after emergence, the interval of days between harvest and last application of the product is still distant from the harvest period. The cultivars URS Guria, URS Tarimba, URS Taura and URS Fapa Slava showed superiority in grain yield with the use of the third application, showing that they are genetically more dependent on fungicide use. Among the cultivars, FAEM 007, FAEM 4 Carlasul and UPFPS Farroupilha stand out, with superiority by the average plus one standard deviation of productivity over the others, in the absence of, and with one and two fungicide applications. Among these cultivars, only FAEM 4 Carlasul was superior under all conditions of fungicide use in terms of productivity and with the smallest necrotic leaf area, evaluated at 105 days after emergence, with two and three fungicide applications. Although FAEM 007 and UPFPS Farroupilha were superior under most conditions based on yield, they were inferior to other cultivars in the expression of reduced necrotic leaf area. These conditions show that not all cultivars with the largest necrotic leaf area will be the ones with the lowest productivity, suggesting that the necrotic area can be compensated by inducing higher photosynthetic efficiency of the healthy tissue area (Table 2).

Table 2. Average grain yield and necrotic leaf area in oat cultivars under conditions of fungicide use in an unfavorable year for oat cultivation (2017).

\begin{tabular}{|c|c|c|c|c|c|c|c|c|}
\hline \multirow{3}{*}{ Cultivar } & \multicolumn{4}{|c|}{ Fungicide } & \multicolumn{4}{|c|}{ Fungicide } \\
\hline & SF & $\begin{array}{l}\mathrm{CF}_{1} \\
(60)\end{array}$ & $\begin{array}{l}\mathrm{CF}_{2} \\
(60 / 75)\end{array}$ & $\begin{array}{l}\mathrm{CF}_{3} \\
(60 / 75 / 90)\end{array}$ & SF & $\begin{array}{l}\mathbf{C F}_{1} \\
(\mathbf{6 0})\end{array}$ & $\begin{array}{l}\mathrm{CF}_{2} \\
(60 / 75)\end{array}$ & $\begin{array}{l}\mathrm{CF}_{3} \\
(60 / 75 / 90)\end{array}$ \\
\hline & \multicolumn{4}{|c|}{ GY $\left(\mathrm{kg} \cdot \mathrm{ha}^{-1}\right)^{(00)}$} & \multicolumn{4}{|c|}{ NLA $_{105 D A E}(\%)$} \\
\hline URS Altiva & C 1103 & B 1792 & A 1909 & A 2109 & A 98 & B 63 & $\begin{array}{l}\text { C } 58 \\
\end{array}$ & B 57 \\
\hline URS Brava & C 1024 & B 1739 & A 1948 & A $1979^{\mathrm{I}}$ & A 99 & B 71 & C 61 & C 58 \\
\hline URS Guará & C 1138 & В 1736 & A 2054 & A 2348 & A 98 & B 70 & C 62 & C 55 \\
\hline URS Estampa & C $790^{I}$ & B $1413^{\mathrm{I}}$ & A $1559^{\mathrm{I}}$ & A $1720^{I}$ & A 99 & В 69 & C 67 & D 53 \\
\hline URS Corona & C 1079 & B 2093 & A $2424^{\mathrm{S}}$ & A 2499 & A 99 & B $60^{s}$ & C 59 & C 58 \\
\hline URS Torena & C $859^{1}$ & В 1609 & A 2217 & A 2352 & A 99 & B 68 & C 64 & C 56 \\
\hline URS Charrua & С 983 & В 1600 & A 2083 & A 2046 & A 99 & B 64 & $\mathrm{C} 60$ & C 57 \\
\hline URS Guria & D 1150 & C 1713 & B 2119 & A 2594 & A 98 & B 73 & $\mathrm{C} 71^{\mathrm{I}}$ & C 62 \\
\hline URS Tarimba & D $877^{1}$ & C $1303^{I}$ & B $1541^{\mathrm{I}}$ & A 2119 & A 99 & B 69 & C 67 & $\mathrm{C} 66^{\mathrm{I}}$ \\
\hline URS Taura & С 1069 & B 1862 & В 1974 & A 2310 & A 99 & B 65 & C 58 & C 56 \\
\hline URS 21 & B 1025 & A 1921 & A 1948 & A 2156 & A 99 & B $84^{\mathrm{I}}$ & C 67 & C 64 \\
\hline FAEM 007 & B $1436^{\mathrm{S}}$ & A $2399^{\mathrm{S}}$ & A $2445^{\mathrm{S}}$ & A 2501 & A 99 & B 74 & C 67 & $\mathrm{C} 65^{\mathrm{I}}$ \\
\hline FAEM 006 & C 1340 & B 2126 & A $2444^{\mathrm{S}}$ & A 2586 & A 99 & B 73 & C 69 & D $48^{\mathrm{S}}$ \\
\hline FAEM 5 Chiarasul & C $1380^{\mathrm{S}}$ & В 1911 & А 2228 & А 2366 & A 99 & В 69 & В 69 & B $67^{1}$ \\
\hline FAEM 4 Carlasul & D $1620^{\mathrm{S}}$ & $\mathrm{C} 2469^{\mathrm{S}}$ & A $2857^{\mathrm{S}}$ & A $3154^{\mathrm{S}}$ & A 99 & B 65 & $\mathrm{C} 53^{\mathrm{S}}$ & D $44^{\mathrm{s}}$ \\
\hline Brisasul & C 1031 & В 1683 & A 2058 & A 2106 & A 99 & B 65 & В 60 & В 56 \\
\hline Barbarasul & B 1220 & A 1732 & A $1802^{\mathrm{I}}$ & A $1939^{\mathrm{I}}$ & A 99 & B 69 & B 62 & B 56 \\
\hline URS Fapa Slava & C 954 & B 1892 & В 2014 & A 2416 & A 99 & B 71 & B 68 & B 61 \\
\hline IPR Afrodite & C 1199 & B 1938 & A 2404 & A 2553 & A 99 & B $58^{\mathrm{S}}$ & B $56^{\mathrm{S}}$ & $\mathrm{C} 42^{\mathrm{S}}$ \\
\hline UPFPS Farroupilha & B $1459^{\mathrm{S}}$ & A $2394^{\mathrm{S}}$ & A $2443^{\mathrm{S}}$ & A 2543 & A 99 & B 69 & B 63 & B 56 \\
\hline UPFA Ouro & C 1237 & B 1900 & A 2110 & A 2362 & A 99 & B $79^{I}$ & B $72^{I}$ & C 62 \\
\hline UPFA Gaudéria & B 1318 & A 1901 & A 1968 & A 2072 & A 99 & B 75 & B $72^{1}$ & B $69^{\mathrm{I}}$ \\
\hline Overall mean & C 1149 & B 1869 & A 2116 & A 2310 & A 99 & B 69 & C 64 & C 58 \\
\hline SD & 212 & 295 & 306 & 304 & 0 & 6 & 5 & 7 \\
\hline Superior $\left({ }^{\mathrm{S}}\right)$ & 1362 & 2164 & 2422 & 2614 & 98 & 63 & 58 & 51 \\
\hline Inferior $\left({ }^{1}\right)$ & 937 & 1574 & 1809 & 2006 & 99 & 75 & 69 & 64 \\
\hline
\end{tabular}

$\mathrm{SF}=$ no fungicide; $\mathrm{CF} 1=$ one fungicide application; CF2 = two fungicide applications; CF3 = three fungicide applications; day of first, second and third fungicide application, respectively; GY = grain yield; NLA105DAE $(\%)=$ necrotic leaf area assessed at 105 days after emergence; $\mathrm{S}=$ above average plus standard deviation for variable GY and below average minus standard deviation for variable NLA105DAE; I = below average minus one standard deviation for variable GY and higher than average plus one standard deviation for variable NLA105DAE; SD = standard deviation. 
In Table 3, in the favorable year (FY) for the cultivation of oat and unfavorable (UY) for leaf diseases (2016), there was adequate use of nitrogen to reach the expectation of productivity, along with less evolution of leaf diseases. This fact is evidenced by the high overall average yield under fungicide use conditions and low necrotic leaf area values, both in the absence of and under the chemical agent use conditions.

Table 3. Average grain yield and necrotic leaf area in oat cultivars under conditions of fungicide use in a favorable year for oat cultivation (2016).

\begin{tabular}{|c|c|c|c|c|c|c|c|c|}
\hline \multirow[t]{2}{*}{ Cultivar } & \multicolumn{4}{|c|}{ Fungicide } & \multicolumn{4}{|c|}{ Fungicide } \\
\hline & SF & $\begin{array}{l}\mathrm{CF}_{1} \\
(60)\end{array}$ & $\begin{array}{l}\mathrm{CF}_{2} \\
(60 / 75)\end{array}$ & $\begin{array}{l}\mathrm{CF}_{3} \\
(60 / 75 / 90)\end{array}$ & SF & $\begin{array}{l}\mathrm{CF}_{1} \\
(60)\end{array}$ & $\begin{array}{l}\mathrm{CF}_{2} \\
(60 / 75)\end{array}$ & $\begin{array}{l}\mathrm{CF}_{3} \\
(60 / 75 / 90)\end{array}$ \\
\hline & \multicolumn{4}{|c|}{ GY (kg.ha $\left.{ }^{-1}\right)$} & \multicolumn{4}{|c|}{ NLA $_{105 \mathrm{DAE}}(\%)$} \\
\hline URS Altiva & C 2893 & B 3478 & A 4423 & A 4467 & A 7 & A 6 & A 3 & B 0 \\
\hline URS Brava & C 3298 & B 3795 & A 4112 & A 4225 & A 7 & A 7 & A 3 & A 2 \\
\hline URS Guará & C 3553 & B 4067 & B 4187 & A 4487 & A 6 & A 6 & A 5 & A $4^{1}$ \\
\hline URS Estampa & B 3266 & A 3625 & A 3671 & A $3748^{1}$ & A 13 & B 8 & $\mathrm{~B} 7^{1}$ & B 3 \\
\hline URS Corona & B $3780^{\mathrm{S}}$ & A $4812^{\mathrm{S}}$ & A $4983^{\mathrm{s}}$ & A $5033^{\mathrm{S}}$ & A 9 & B 3 & B 2 & B 0 \\
\hline URS Torena & D 2861 & C 3462 & B 3886 & A 4271 & A 4 & $\mathrm{~A} 2^{\mathrm{S}}$ & A 1 & A 0 \\
\hline URS Charrua & B 3584 & A 4048 & A 4131 & A 4152 & A $18^{1}$ & B 4 & B 2 & B 0 \\
\hline URS Guria & C $2311^{1}$ & B $3296^{1}$ & B $3440^{1}$ & A $3734^{1}$ & A 8 & B 3 & B 1 & B 0 \\
\hline URS Tarimba & D 3351 & C 3934 & B 4249 & A 4661 & A $20^{1}$ & B $11^{1}$ & B $6^{1}$ & B 3 \\
\hline URS Taura & D $2231^{1}$ & C $3366^{1}$ & B 4145 & A 4804 & A 13 & B 5 & B 2 & B 0 \\
\hline URS 21 & B 3312 & A 3569 & A 3662 . & A $3755^{1}$ & A 14 & B 4 & B 2 & B 0 \\
\hline FAEM 007 & C $3752^{\mathrm{s}}$ & B $4233^{\mathrm{s}}$ & A $4861^{\mathrm{S}}$ & A $4924^{\mathrm{S}}$ & A 15 & B 5 & B 4 & B 1 \\
\hline FAEM 006 & D 3461 & С 3929 & B 4034 & A 4543 & A $18^{1}$ & B $12^{1}$ & C 3 & C 1 \\
\hline FAEM 5 Chiarasul & C 3036 & B 3783 & B 3727 & A 4009 & A 4 & B 3 & B 2 & B 2 \\
\hline FAEM 4 Carlasul & B $3802^{\mathrm{S}}$ & A 4127 & A 4128 & A 4182 & A $3^{\mathrm{S}}$ & $\mathrm{A} 2^{\mathrm{S}}$ & A 1 & A 0 \\
\hline Brisasul & D 3362 & C 3827 & B 4172 & A $4975^{\mathrm{S}}$ & A 5 & A 3 & A 2 & A 1 \\
\hline Barbarasul & D 3358 & C 4171 & B 4453 & A 4833 & A 5 & A 4 & A 2 & A 1 \\
\hline URS Fapa Slava & C $2081^{1}$ & B $3373^{1}$ & A $3562^{1}$ & A $3621^{1}$ & A $32^{1}$ & B 8 & B 4 & B 0 \\
\hline IPR Afrodite & $\mathrm{C} 4096^{\mathrm{S}}$ & B $4549^{\mathrm{S}}$ & B $4687^{\mathrm{S}}$ & A $5195^{\mathrm{s}}$ & A 5 & A 4 & A 2 & A 0 \\
\hline UPFPS Farroupilha & D 3354 & C 3833 & В 4104 & A 4416 & A 8 & A 6 & A 4 & A 3 \\
\hline UPFA Ouro & C 2736 & B $3131^{1}$ & A $3413^{1}$ & A $3641^{1}$ & A 10 & B 5 & B 4 & B 3 \\
\hline UPFA Gaudéria & B 3035 & A 3502 & A $3552^{1}$ & A $3614^{1}$ & A 7 & B 4 & B 2 & B 1 \\
\hline Overall mean & D 3200 & C 3814 & B 4072 & A 4331 & A 10 & B 5 & B 3 & B 1 \\
\hline SD & 518 & 417 & 437 & 506 & 7 & 3 & 2 & 1 \\
\hline Superior $\left({ }^{S}\right)$ & 3718 & 4231 & 4509 & 4837 & 4 & 3 & 1 & 0 \\
\hline Inferior $(1)$ & 2683 & 3398 & 3635 & 3825 & 17 & 8 & 5 & 3 \\
\hline
\end{tabular}
$(60)=$ day of fungicide application after emergence; $(60 / 75)=$ day of first and second fungicide application, respectively; $(60 / 75 / 90)=$ day of first, second and third fungicide application, respectively; GY = grain yield; NLA105DAE $(\%)=$ necrotic leaf area assessed at 105 days after emergence; $\mathrm{S}=$ above average plus standard deviation for variable GY and below average minus standard deviation for variable NLA105DAE; I = below average minus one standard deviation for variable GY and higher than average plus one standard deviation for variable NLA105DAE; SD = standard deviation.

The general average values indicate that a single application of fungicide at 60 days after emergence was sufficient to reach values close to the desired yield expectation in most of the cultivars. Under this cultivation condition, the cultivars URS Corona, FAEM 007 and IPR Afrodite showed superiority of grain yield under all conditions of fungicide use with a long interval from application to harvest. Of these cultivars, FAEM 007 also showed superior productivity behavior in 2017. Although FAEM Carlasul, a highlight of 2017, did not show superior behavior in the conditions of fungicide use in 2016, grain yield was higher than for the others in the absence of fungicide and in the overall average plus or minus a standard deviation. This agricultural year condition was not suitable for effective 
analysis of disease progress and identification of cultivars more responsive to reducing fungicide use with longer interval from application to harvest.

In Table 4, in the intermediate year (IY) for oat cultivation and favorable (FY) for disease progression, the expected productivity was not reached, mainly due to the great effect of oat leaf diseases. This condition makes it easier to identify more resistant and resilient cultivars at a longer interval of application to grain harvest. In this situation, the URS Altiva and URS Guria cultivars had superior grain yield for the average plus a standard deviation in the absence and presence of fungicide for one and two applications at 60 and 75 days after emergence.

Table 4. Average grain yield and necrotic leaf area in oat cultivars under conditions of fungicide use in an intermediate year for oat cultivation (2015).

\begin{tabular}{|c|c|c|c|c|c|c|c|c|}
\hline \multirow[t]{3}{*}{ Cultivar } & \multicolumn{4}{|c|}{ Fungicide } & \multicolumn{4}{|c|}{ Fungicide } \\
\hline & SF & $\begin{array}{l}\mathbf{C F}_{1} \\
(60)\end{array}$ & $\begin{array}{l}\mathrm{CF}_{2} \\
(60 / 75)\end{array}$ & $\begin{array}{l}\mathrm{CF}_{3} \\
(60 / 75 / 90)\end{array}$ & SF & $\begin{array}{l}\mathbf{C F}_{1} \\
(60)\end{array}$ & $\begin{array}{l}\mathrm{CF}_{2} \\
(60 / 75)\end{array}$ & $\begin{array}{l}\mathrm{CF}_{3} \\
(60 / 75 / 90)\end{array}$ \\
\hline & \multicolumn{4}{|c|}{ GY $\left(\mathrm{Kg} \mathrm{ha}^{-1}\right)$} & \multicolumn{4}{|c|}{ NLA $_{105 D A E}(\%)$} \\
\hline URS Altiva & $\mathrm{C} 2321^{\mathrm{S}}$ & C $2696^{\mathrm{S}}$ & B $3487^{\mathrm{S}}$ & A $4236^{\mathrm{S}}$ & A 69 & B 30 & C 7 & $\mathrm{C} 2$ \\
\hline URS Brava & D 1229 & C 2393 & B 3191 & A $3993^{\text {S }}$ & A 53 & B 14 & C 7 & $\mathrm{C} 2$ \\
\hline URS Guará & C 1486 & B 2083 & A 3166 & A 3453 & A 77 & B 20 & $\mathrm{C} 9$ & $\mathrm{C} 0^{\mathrm{s}}$ \\
\hline URS Estampa & D 1555 & C 2393 & B 2822 & A 3302 & A $28^{\mathrm{S}}$ & В 22 & B $19^{\mathrm{I}}$ & C 10 \\
\hline URS Corona & D 804 & C 2030 & В 2824 & A 3333 & A $98^{1}$ & A $90^{1}$ & $\mathrm{C} 6$ & B $22^{1}$ \\
\hline URS Torena & C 1348 & B 2377 & A 2783 & A $2892^{\mathrm{I}}$ & A 69 & B 41 & C $18^{\mathrm{I}}$ & C 16 \\
\hline URS Charrua & C 1616 & B $2662^{\mathrm{S}}$ & A 3078 & A 3107 & A 63 & B 24 & C 10 & $\mathrm{C} 4$ \\
\hline URS Guria & C $1949^{\mathrm{S}}$ & B $2681^{\mathrm{S}}$ & A $3413^{\text {S }}$ & A 3517 & A 62 & B 16 & $\mathrm{C} 8$ & $\mathrm{C} 2$ \\
\hline URS Tarimba & C 1386 & C $1646^{\mathrm{I}}$ & B $2672^{\mathrm{I}}$ & A 3160 & A 55 & B 28 & C 14 & C 11 \\
\hline URS Taura & C 863 & B 1813 & B $2152^{1}$ & A $2775^{1}$ & A 89 & B 26 & C 14 & C 9 \\
\hline URS 21 & C 1552 & B 2192 & A 3071 & A 3104 & A 68 & B 26 & C 14 & $\mathrm{C} 9$ \\
\hline FAEM 007 & C $579^{1}$ & B $1194^{\mathrm{I}}$ & A 2922 & A $2923^{\text {I }}$ & A 85 & B $69^{\mathrm{I}}$ & D 10 & $\mathrm{C} 24^{\mathrm{I}}$ \\
\hline FAEM 006 & D $749^{I}$ & C 2035 & B 3265 & A 3660 & A $97^{\mathrm{I}}$ & В 56 & $\mathrm{D} 4^{\mathrm{s}}$ & C 14 \\
\hline FAEM 5 Chiarasul & D $727^{I}$ & C $1304^{\text {I }}$ & B 3353 & A $3923^{\mathrm{S}}$ & A $96^{\mathrm{I}}$ & B $60^{\mathrm{I}}$ & $\mathrm{C} 6$ & C 11 \\
\hline FAEM 4 Carlasul & C 1352 & B 2165 & A $3414^{\text {S }}$ & A 3514 & A 75 & В 33 & C 9 & C 16 \\
\hline Brisasul & C 1066 & В 2237 & A $3516^{\mathrm{S}}$ & A 3700 & A $37^{\mathrm{S}}$ & A 34 & B 9 & B 10 \\
\hline Barbarasul & $\mathrm{C} 680^{1}$ & B 1854 & A $3579^{\mathrm{S}}$ & A 3739 & A 86 & A $82^{1}$ & B 12 & B 4 \\
\hline URS Fapa Slava & C 1189 & В 1719 & A 3096 & A 3159 & A 49 & A 46 & B $24^{\text {I }}$ & B $17^{\mathrm{I}}$ \\
\hline IPR Afrodite & D $566^{\mathrm{I}}$ & $\mathrm{C} 1527^{\mathrm{I}}$ & В 2802 & A 3382 & A $94^{\text {I }}$ & В 37 & $C 5^{\mathrm{s}}$ & $\mathrm{C} 4$ \\
\hline UPFPS Farroupilha & C 1324 & B 2448 & A 3215 & A 3464 & A 61 & B 28 & $\mathrm{C} 4^{\mathrm{S}}$ & $\mathrm{C} 2$ \\
\hline UPFA Ouro & D 1386 & C 2290 & B 2791 & A 3378 & A $31^{\mathrm{S}}$ & B $6^{\mathrm{s}}$ & B $5^{\mathrm{s}}$ & B $0^{\mathrm{s}}$ \\
\hline UPFA Gaudéria & D 1308 & C 2163 & B $2601^{1}$ & A 3222 & A $27^{\mathrm{s}}$ & B 15 & B 12 & B 8 \\
\hline Overall mean & C 1229 & В 2086 & A 3055 & A 3406 & A 67 & B 36 & C 10 & C 9 \\
\hline SD & 448 & 422 & 353 & 368 & 23 & 22 & 5 & 7 \\
\hline Superior $\left({ }^{\mathrm{S}}\right)$ & 1677 & 2508 & 3409 & 3774 & 44 & 14 & 5 & 2 \\
\hline Inferior $\left({ }^{\mathrm{I}}\right)$ & 781 & 1665 & 2702 & 3038 & 89 & 59 & 15 & 16 \\
\hline
\end{tabular}

$\mathrm{SF}=$ no fungicide $\mathrm{CF} 1=$ one fungicide application; $\mathrm{CF} 2=$ two fungicide applications; $\mathrm{CF} 3=$ three fungicide applications;
$(60)=$ day of fungicide application after emergence; $(60 / 75)=$ day of first and second fungicide application, respectively; $(60 / 75 / 90)=$ day of first, second and third fungicide application, respectively; GY = grain yield; NLA105DAE (\%) = necrotic leaf area assessed at 105 days after emergence; $\mathrm{S}$ = above average plus standard deviation for variable GY and below average minus standard deviation for variable NLA105DAE; I = below average minus one standard deviation for variable GY and higher than average plus one standard deviation for variable NLA105DAE; SD = standard deviation.

Among these, URS Altiva also was superior with the third application at 90 days after emergence, with a significantly higher average yield compared to both applications at 60 and 75 days after emergence. The cultivars URS Brava and FAEM 5 Chiarasul were superior with the three fungicide applications, with similar yield to the desired expectation of $4000 \mathrm{~kg}$ ha-1. Although all three applications were carried out, the purpose of the study was to start with earlier applications and at the most, directing three fungicide application 
times while still maintaining a considerably long interval from application to harvest, for greater food safety of the raw material produced. The cultivars with the highest yield response, such as URS Altiva and URS Guria, under neither condition showed superiority based on smaller necrotic area, being within the distribution average of plus or minus one standard deviation. The cultivar with superiority of smaller necrotic leaf area was the cultivar UPFA Ouro, standing out in the absence and presence of fungicide. On the other hand, although it had a smaller necrotic area, under none of the conditions did it show superior grain yield (Table 4).

The results show that cultivars with higher grain yield do not necessarily show smaller necrotic leaf area, indicating that genotypes with genes that are more adjusted to grain yield are not always associated with genes that promote greater disease resistance, justifying that these genes are independent about the expression of these characters. Because the necrotic leaf area does not show a direct reduction in oat grain yield, it is hypothesized that there are resistance mechanisms not directly linked to the reduction of leaf necrosis, but on the photosynthesis efficiency to compensate for the increase in necrotic tissue. Therefore, generating the possibility of new strategies for selection of more resistant genotypes, from the perspective of reducing fungicide use and living with the disease, provided that it maintains adequate productivity.

This possibility can be justified by the presence of quantitative inheritance genes (Vieira et al., 2006) and linked to biochemical changes, generating physiological efficiency to compensate for necrotic tissue (Matiello et al., 1997).

The presence of leaf diseases in oat cultivation causes significant losses in productivity. Among leaf diseases, leaf rust and yellow spot are those that cause significant damage to productivity (Oliveira et al., 2014; Nazareno et al., 2017). The genetic resistance found in oat cultivars is inefficient and can be easily overcome by new pathogenic populations due to pathogen selection pressure as a result of long-term large-scale cultivation practices (Montilla-Bascón, et al., 2015). Oat cultivars recommended for cultivation in Brazil exhibit distinct behaviors in response to weather conditions and the development of leaf diseases (Marcos et al., 2015). This distinction in behavior may be justified by the different yield responses obtained in the evaluation of different cultivars (Hawkesford et al., 2013). In addition, there has been distinct behavior between grain yield performance and resistance to leaf or stress diseases, strengthening the independence character among the genes responsible for the expression of these traits. In a review study, Finnan and Spink (2016) also found divergences of results regarding the relationship between grain yield and healthy leaf area of oats. Neto et al. (2019) conducted a study of yield performance and reaction of white oat cultivars to rust and leaf spot, finding acceptable yield averages in the absence of fungicide. A condition that generates the possibility of adjusting genotype versus management technology interaction in the perspective of development of organic production of this cereal.

Zambiazzi et al. (2018) observed that the use of fungicide significantly increased the productivity of a large number of soybean cultivars, but did not carry out residual oil and grain contamination studies by the form and / or number of pesticide applications. In oat, Mourtzinis, Conley, Gaska (2015) found a significant increase in grain yield through the use of fungicide without reducing the nutritional quality characteristics of the grains, but without results that measure the existence of pesticide residue. Most articles published on the topic of 'pesticides' focus on the acute effects and type of exposure to the product. 
Research on the ingestion of contaminated food and its short and long term exposure has not been found, making it urgent to analyze the food exposure to the health problems arising from the use of agrochemicals (Lopes \& Albuquerque, 2018). The United Nations Sustainable Development Goals represent an urgent and formidable challenge for scientists and society for the urgent need to transform agriculture and the food sector into achieving food security with social and environmental sustainability (Dhankher \& Foyer, 2018). In this context, food security needs to be promoted from new concepts, which requires a much broader, systems-based approach, including environment, technology, economy and society, at all levels of the organization (Nüsslein \& Dhankher, 2016).

The study presented not only promotes the possibility of proposing a management technology that increases the interval of fungicide application to oat grain harvest, as well as the identification of cultivars more adjusted to this system, ensuring the elaboration of products with greater food safety. In addition, to propose advances on adjacent mechanisms of disease resistance, by inducing elements of physiological efficiency of healthy cells, in a way, associated with culture resilience, enabling the development of genotypes adjusted to the living of the disease, without economic risks to production, providing a foundation for sustaining food security.

\section{CONCLUSIONS}

Most of the oat cultivars had little influence on productivity with the third application of fungicide at 90 days after emergence. Therefore, increasing the interval between application and harvest with just two applications, at 60 and 75 days after emergence is justified.

The cultivars FAEM 4 Carlasul, URS Altiva and URS Guria had high yields under most fungicide use conditions, allowing a long interval between the last application and grain harvest.

\section{ACKNOWLEDGMENTS}

We thank CAPES, CNPq, FAPERGS and UNIJUI for financial support and for the Scientific and Technological Initiation Scholarship, Postgraduate Scholarship and Research Productivity Grant. We thank the graduate program in Mathematical Modeling and Environmental Systems and Sustainability at UNIJUÍ for the resources available for the development of this research, which was part of the master's dissertation the first author.

\section{CONFLICTS OF INTEREST}

The authors declare no conflict of interest.

\section{REFERENCES}

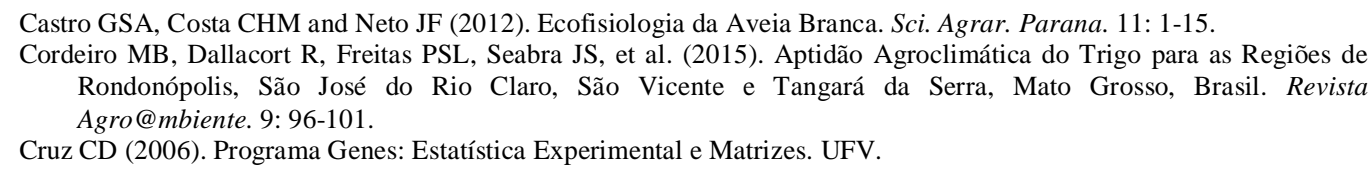


Dhankher OP and Foyer Christine H (2018). Climate Resilient Crops for Improving Global Food Security and Safety. Plant Cell Environ. 41: 877-884.

Dietz JI, Schierenbeck M and Simón MR (2019). Impact of Foliar Diseases and its Interaction with Nitrogen Fertilization and Fungicides Mixtures on Green Leaf Area Dynamics and Yield in Oat Genotypes with Different Resistance. Crop Protec. 121: 80-88.

Dornelles EF (2018). Modelagem Matemática da Elaboração de Grãos de Aveia mais Saudáveis a Alimentação pela Redução de Uso de Fungicida e Maior Intervalo Entre a Colheita e Última Aplicação. Master's thesis, Universidade Regional do Noroeste do Estado do Rio Grande do Sul, UNIJUÍ, Ijuí.

Finnan JM and Spink J (2016). Identification of Yield Limiting Phenological Phases of Oats to Improve Crop Management. J. Agric. Sci. 155: 1-17.

Hawkesford MJ, Araus JL, Park R, Calderini D, et al. (2013). Prospects of Doubling Global Wheat Yields. Food Energy Secur. 2: 34-48.

Karise R, Dreyersdorff G, Jahani M, Veromann E, et al. (2016). Reliability of the Entomovector Technology Using Prestop-Mix and Bombus terrestris L. as a Fungal Disease Biocontrol Method in Open Field. Sci. Rep. 6: 31650.

Kuhnem JPR, Casa RT, Rizzi FP, Moreira EM, et al. (2009). Desempenho de Fungicidas no Controle de Doenças Foliares em Trigo. Rev. Cienc. Agrovet. 8: 35-42.

Lopes CVA and Albuquerque GSC (2018). Agrotóxicos e Seus Impactos na Saúde Humana e Ambiental: uma Revisão Sistemática. Saúde Debate. 42: 518-534.

Marcos MF, Jank L, Fernandes CD, Verzignassi JR, et al. (2015). Reação à Bipolaris Maydis, Agente Causal da Mancha Foliar, em Híbridos Apomíticos de Panicum Maximum. Summa Phytopathol. 41: 197-201.

Martinelli JA, Chaves MS, Federizzi LC and Savi V (2009). Expressão da Resistência Parcial à Ferrugem da Folha da Aveia Presente na Linhagem MN841801, no Ambiente do Sul do Brasil. Cienc. Rural. 39: 1335-1342.

Matiello RR, Barbieri RL, Carvalho, FIF. (1997). Resistência das Plantas a Moléstias Fúngicas. Ciênc. Rural, 27: 161168.

Montilla-Bascón G, Rubiales D, Altabella T and Prats E (2015). Free Polyamine and Polyamine Regulation During Prepenetration and Penetration Resistance Events in Oat Against Crown Rust (Puccinia Coronata f. sp. avenae). Plant Pathol. 65: 392-401.

Mourtzinis S, Conley SP and Gaska JM (2015). Agronomic Management and Fungicide Effects on Oat Yield and Quality. Crop Sci. 55(3): 1290-1294.

Nazareno ES, Li F, Smith M, Park RF, et al. (2017). Puccinia coronata f. sp. avenae: A Threat to Global Oat Production. Mol. Plant Pathol. 19(5): 1047-060.

Neto SS O, Zeffa DM, Arruda KMA and Riede CR (2019). White Oat Agronomic Performance and Cultivar Reactions to Leaf Rust and Leaf Spot. Agro. Sci. Biotec. 5: 24-31.

Nüsslein K and Dhankher OP (2016). Project Management: Food Security Needs Social-Science Input. Nature. 535: 37 37.

Oliveira AR, Boller W, Forcelini CA, Blum R, et al. (2007). Fungicidas, Doses e Volumes de Calda no Controle Químico da Ferrugem da Folha da Aveia (Puccinia coronata f. Sp. Avenae). Engenharia Agrícola. 27 (spe): 48-55. https://doi.org/10.1590/S0100-69162007000200008.

Oliveira DM, Souza MA, Rocha VS and Assis JC (2011). Desempenho de Genitores e Populações Segregantes de Trigo Sob Estresse de Calor. Bragantia. 70: 25-32.

Oliveira EAP, Zucareli C, Fonseca ICB, Oliveira JC, et al. (2014). Foliar Fungicide and Environments on the Physiological Quality of Oat Seeds. J. Seed Sci. 36: 15-24.

Oliveira GM, Pereira DD, Camargo LCM, Balan MC, et al. (2015). Dose e Taxa de Aplicação de Fungicida no Controle da Ferrugem da Folha (Puccinia triticina) e da Mancha Amarela (Pyrenophora tritici repentis) do Trigo. Semina: Ciênc. Agrárias. 36: 17-30.

Ray DK, Mueller ND, West PC and Foley JA (2013). Yield Trends are Insufficient to Double Global Crop Production by 2050. Plos One. 8: 66428.

Romitti MV, Dornelles EF, Silva JAG, Marolli A, et al. (2017). The Sowing Density on Oat Productivity Indicators. Afri. J. Agric. Res. 12: 905-9150.

Scremin OB, Silva JAG, Mamann ATW, Marolli A, et al. (2017). Nitrogen and Hydrogel Combination in Oat Grains Productivity. Internat. J. Develop. R. 7: 13896-13903.

Silva JAG, Wohlenberg MD, Arenhardt EG, Oliveira AC, et al. (2015). Adaptability and Stability of Yield and Industrial Grain Quality With and Without Fungicide in Brazilian Oat Cultivars. Am. J. Plant Sci. 6: 1560-1569.

Souza JLM, Gerstemberger E and Araujo MA (2013). Calibração de Modelos Agrometeorológicos para Estimar a Produtividade da Cultura do Trigo, Considerando Sistemas de Manejo do Solo, em Ponta Grossa-PR. Rev. Bras. Meteorol. 28: 409-418.

Souza TT, Pereira JLAR and Souza TT (2015). Avaliação da Produtividade de Milho e Controle de Doenças Foliares. Rev. Agrogeoa. 7(3): 31-37.

Tormen NR, Lenz G, Minuzzi SG, Uebel JD, et al. (2013). Reação de Cultivares de Trigo à Ferrugem da Folha e Mancha Amarela e Responsividade a Fungicidas. Cienc. Rural. 43: 239-246. 
Vieira EA, Carvalho FIF, Chaves MS, Oliveira AC, et al. (2007). Herança da Resistência à Ferrugem da Folha da Aveia (Puccinia coronata f. sp. avenae Fraser \& Led.) em Genótipos Brasileiros de Aveia Branca. Ciênc. Rural. 36: 135141.

Zambiazzi EV, Bruzi AT, Zuffo AM, Soares IO, et al. (2018). Effects and Management of Foliar Fungicide Application on Physiological and Agronomical Traits of Soybean. Aust. J. Crop Sci. 12(2). 